\title{
Tools of the game. Qualitative digital methodologies for the e-sports research
}

\author{
Marcin Zaród \\ Digital Sociology Working Group / University of Warsaw
}

DOI: http://dx.doi.org/10.18778/1733-8069.17.1.03

\section{Keywords:}

sociology of sport, e-sport research, ethnography, netnography, digital sociology

\begin{abstract}
This article adopts methodology from digital qualitative studies in order to discuss issues specific to e-sport research in the sociology of sport. The applied concepts are built on a critical discussion of the existing theories and cases from the author's fieldwork on e-sports among hackers. The employed theories and methods are taken from virtual ethnography, netnography, and digital ethnography. These approaches are discussed critically, especially regarding their relations with Science and Technology Studies and Communication and Media Studies.

The paper advocates acknowledging the cognitive approach from virtual ethnography, while dropping the approach to virtuality in favor of other theories of spatiality, with the theory of infrastructure as the backbone. It discusses the usability of Kozinets' netnographical genres and their potential differences, but proposes a more practical solution to autonetnography. Finally, it shows how different frameworks in digital ethnography can be used in the context of e-sport research. The last part of the article is devoted to some practical advice based on discussions and practice.
\end{abstract}

Marcin Zaród, PhD, a sociologist of science, formerly a physicist. He specializes in the constructivist approach and studies of the social aspects of computer security. He did ethnographies among hackers, CTFers, and roboticists. Personally, he likes puzzles, cats, board games, and social justice.

\section{Contact details:}

Wydział Socjologii UW

Karowa 18, 00-324 Warszawa

e-mail address: m.zarod@is.uw.edu.pl

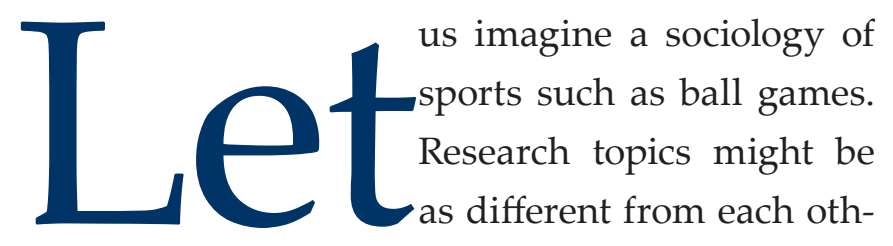
er as football is from volleyball. At the same time, after putting in some work, one will see similarities in the fields, players, and strategies. One might also see similarities in tacit knowledge (Jakubowska 2017), political entanglements (Schimmel 2017; Kossakowski, Nosal, and Woźniak 2020), or many other 
topics which have been studied for several decades in this research area (Seippel 2018). However, some balls are more elusive than others, some rules are harder to understand, and some matches are harder to read. The same goes for the sociology of e-sports, especially in the debate on methods. They should definitely be included in the studies, but at the same time they somewhat evade the usual perceptions, habits, and intuitions.

If one has experience in playing any ball game, or in doing any ethnography, they are probably familiar with the paradox of peripheral vision. Sometimes it is easier to see things by not focusing on them, but by looking elsewhere instead. Paradoxically, by putting a key object out of sight, one refocuses on it. They get closer to the action by distancing themselves, or get distance through total immersion. As both ethnographers and players know, there is a whole world between the desk and the field (Strathern 1999).

This is the basic premise of this article - to provide a new focus on qualitative methodologies for studying e-sports by looking somewhat away from the sociology of sport. In terms of methodology, I will revisit several concepts from digital sociology, such as virtual ethnography (Hine 2015), netnography (Kozinets 2011), and digital ethnography (Pink et al. 2016).

I need a playing field in order to try some ideas, be it a methodological tiki-taka or practical spiking. This is somewhat problematic, as I am more of a sociologist of science than a sociologist of sport. This is why I will use examples from my ethnography of hacking tournaments, taken from within the framework of ethnography of the laboratories (Latour 1987). Since this approach focused on knowledge-making in laboratories just before digital era, I have modi- fied some of the concepts to keep up with the digital (Vertesi, Ribes, and DiSalvo 2019). Hacking tournaments could be analyzed both as a sport and as a laboratory practice. In this paper, I am focusing on the former one. This will be the field for our Ashes, our play-offs, and our World Series.

I will begin with setting up the scene and recounting an age-old paradox, which I encountered at the beginning of social studies into the Internet. Then, I will introduce the basics of 'Capture the Flag' (CTF) hacking tournaments as well as the methodological premises of my study. Then, I will use cases from my study to highlight the applications and pitfalls of four approaches to digital qualitative methods. The goal is to provide some new tools for the game and to take the concepts from studying things that are far away from the sociology of sport, but that can offer a new insight into e-sports. Game on.

\section{Internet, ethnography, and methodologies - the preliminary ordering}

"What established anthropological concepts and methods would be appropriate to the study of cyberculture? How, for instance, will notions of community, fieldwork, the body, nature, vision, the subject, identity, and writing be transformed by the new technologies?" Although they seem contemporary, these questions were asked in the 1990s by Arturo Escobar (Escobar 1994:214-215). The digital domain was treated as a separate subculture, or cyberculture, if you will. Following this concept, the Internet was studied as a separate place, a foreign and distant one.

In 2020, the Internet is no longer a place. It became ubiquitous, permeating almost every practice and society. It is not a location, it is something common. 
Most likely, it is the same thing for players and fans of e-sports. It can be turned off so that one can refocus or just rest, but otherwise it just is (Caliandro 2017).

The passage of time did not remove the tension within ethnography and its digital reincarnations. If the Internet is familiar, then how do we conduct the ethnography of it? Through the history, ethnography used amazement as a cognitive boost to get a clearer view. But how to follow historical and methodological traditions when the digital became the mundane? While ethnographic amazement should be approached cautiously due to its colonial origins, another argument for strangeness can be built based on the premise of self-care. If there is no difference between a field and a home, then the digital ethnographer never leaves work.

This is the central tension visible within all the methodologies discussed in this paper. Virtual ethnography leans closer to the domain of strangeness, while netnography sees the digital as something familiar. Digital ethnography takes a middle route, as it argues for studying everyday digital practices and things in addition to studying uncommon events and somewhat separated social worlds.

In the case of e-sports, I propose to do the same, i.e. to use netnography not when e-sport is something special, but when it moves between social media and different scales of events. This approach is also useful for mixed methods, as it is not concerned with the anthropological heritage and its challenges. Digital ethnography might be helpful if one wishes to study a particular event or practice of watching games in private spaces, such as streams, comments, and fan studies networks. Lastly, virtual ethnography is more of a historical mark rather than a useful methodological guide. As its author,
Christine Hine, shifted toward "ethnography for the Internet," it can be useful for studying liminal zones between the digital and the physical, such as embodiment at the scale of players or institutions. In result, this article takes from four methodological venues: virtual ethnography, netnography, digital ethnography and ethnography for the Internet.

The familiar / strange 1 tension, as well as these four approaches, will form a backbone of my article. Certainly, there are other ways, such as the digital-methods approach and its ethnographical adaptation (Caliandro 2017). However, I decided to choose these particular four approaches, because they fit best into my field while at the same time remaining distinctive and minimally overlapping.

There are also differences between the sociology of sport and digital methodologies. For example, digital ethnography uses the concept of a ritual in a more private, intimate setting, such as home. The ritual is understood through the performative framework, more toward media/mediated event rather than traditional Durkheimian and Turnerian theoretical origins. These origins have been a basis for important thoughts in the theory of sociology of sport (Guttmann 2012) and they are still easy to trace in studies of mass sports events (Kossakowski et al. 2020). Despite this, they are absent in the theories and methodologies of e-sports (Reitman et al. 2020). Using concepts from the virtual ethnography of events might help to bridge this gap.

\section{Ethnography of hacking laboratories - the setting and the methods of my study}

While my analysis of hacking tournaments is still pending, I would like to offer some basic information about the theme and methodology of my study. 
I will use examples taken from my studies of hackers' e-sport. A team is formed by 5-15 persons who try to solve puzzles of computer security, cryptography, programing, and electronics. Puzzles could be solved on-site as well as remotely. They are provided by one team, one which assumed the role of the organizer. Each game takes from several hours to several days, often accompanying a security conference or other hacking meeting. These games go by the name 'Capture the Flag' (CTF), with equivalents of the annual league and championships.

CTFs are highly communal, i.e. the same people play them, organize them, and manage scoring charts. The CTF community often works beyond the boundaries of a single institution, be it a company, an academic research group, or a government security task force.

I observed about ten tournaments, mostly at the highest international level, with local games as supplementary material. I shadowed players and organizers or task authors, as well as the audience. I conducted observations and interviews both classically and by computer, using chats, emails, and the content analysis of post-tournament documentation. I carried out twenty full-length interviews with players as well as recorded about forty in-situ conversations.

The study of CTFs was an off-shot of a larger ethnographical project, which involved a three-year ethnography of local hacking groups in Europe, mostly in Poland and in Germany, with supplementary sites in Sweden and Denmark. As the participants of this study took interest in CTFs, I followed them and extended the scope of my study. They often acted as players or viewers of various CTFs, which is why I had an advantage when I tried to understand the details of the game and the meaning it has for different groups of hackers and security experts.

Both the CTF research and the hacking ethnography were conducted openly, with consent given at the level of an individual as well as of teams and communities. I discussed my findings with the community, delivering talks and workshops during the events and in the place where I worked.

Despite some stereotypes about hackers, the studies were not particularly dangerous or illegal, although they were demanding in terms of the complex knowledge as well as a mix of seriousness and irony that characterizes the epistemic cultures of hacking. I had the advantage of blending in - physically and cognitively - as a male-looking, short-sighted, nerdy, overweight graduate of physics (Zaród 2018). In spite of having had little knowledge of computer security, I was mistaken for a hacker, also by the officers of government agencies.

All my studies are heavily influenced by traditions of ethnographies of laboratories as well as science and technology studies. I did the initial study within the Actor-Network Theory framework, relying mostly on Bruno Latour's Reassembling the Social (2005), with supplements from other classic studies (Knorr Cetina 1999).

\section{Learning from virtual ethnography - space and cognition}

The archaeology of qualitative digital methods lies outside the scope of this paper, but virtual ethnography is worth discussing in detail. It is situated at the intersection of those "old" studies of the Internet as a space and the "new" studies of the Internet as something common. The metaphor of the separate 
place remains intuitive, especially for scholars less immersed in digital media. I shall make it a starting point.

Virtual Ethnography by Christine Hine (2000) is an important landmark, as its publication had marked the era just before the massive spread of Facebook and other social media. The author treated digital networks as a peculiar form of space/field. She focused on virtuality, understanding it - roughly speaking - as an issue of artificialness, the exclusion of materiality. For her method, authenticity and identity were performed at the intersection of the virtual and the real.

Our Internet has changed much since Hine's studies. For once, it became self-evident and fragmented. CTF participants rarely saw the Internet as a whole. Rather, they focused on the system and the tools. Answering the question about the worst prepared task, one player told me:

Probably the one which involved, I don't know, a virtual box image, which was not fully there. We managed to somehow get much data out of this image dispatching virtual box. I do not know exactly anymore, but in the end the solution was to grab a PDF which was appended on the file and just bruteforce the password. I did this task, as it could have been remarkably interesting. The final route went through the virtual box and involved, I don't know, getting the clipboard contents, or something like that. ${ }^{1}$

Here, the Internet is for the player what society is for myself as a sociologist, i.e. it is simultaneously tak-

\footnotetext{
${ }^{1}$ All talks and interviews were conducted in English or translated by the Author. Even in the case of Polish, German or international teams recorded fresh talks were often conducted in mixture of English and other languages. In all cases: the Author is responsible for the translation.
}

en for granted, ever-present, and invisibly abstract. It is a mechanism, an organism, a territory. A tool and a riddle. It is too general to be useful, but at the same time it is constantly being modeled in my mind, shifting between different metaphors. Here, the CTF Player is not talking in terms of space, but, rather, in terms of tools for solving the problem. The game is not a physical space, but a peculiar state one of problem-solving, of a set of engineering constraints, of tools and ruses.

Hine understands virtuality in a more classic way, namely only through the perspective of people in the most direct, material sense. My interpretation of CTF is closer to the thinking line developed by Paul Dourish (2017), who takes virtuality as a materialization of something new. Rather than reasoning in terms of "what is lacking in CTF in comparison to physical sports," I prefer to shift my attention to thinking in terms of "what is materialized, touched and operated during CTF tournament." In this regard, virtuality is a function of immersions of players, their minds, and their actions. One does not necessarily need a VR headset to access this kind of virtuality; one does not even need a computer. This kind of virtuality is created during a game of chess, but also during a training session of aikido or in the course of synchronous swimming (Muntanyola-Saura and Sánchez-García 2018).

What could we learn from the sociology of sport? I believe that we can move away from comparing physical spaces of sports to those in e-sport (see Figure 2). As I see it, comparing cognitive spaces is much more useful, as it builds a more interesting case than the interpretation of e-sport as an ersatz of regular sports. In other words, the focus should not be on what is missing, but, rather, on what is shared between sports' and e-sports' mind spaces. When 
physical thinking precedes manual intuitions, how is the game read by players, judges, coaches, and viewers? This approach to virtuality goes naturally with other cognitive approaches to the sociology of sport, such as the focus on tacit knowledge (Jakubowska 2017).

Does this mean that space becomes irrelevant? I do not think so. Drawing from Hine, I would say that space still has to be maintained and studied. It would be politically naïve to forget about the control over spaces in e-sports as well as about the politicization of spaces in sports in general (Kossakowski et al. 2020). In this aspect, I am following Cem Abanazir's suggestion (2018) that issues of software production for sports should be included in video games. In other words, the regular-sports-related sociological question about to whom the playing field belongs is reformulated when one considers that the playing field is virtual, i.e. existing not only in terms of a singular event or fanbase, but also as a salable software product. Additionally, because the virtuality is much easier to change, one does not only play in some of the spaces; they play with them, using them as a tool or as a strategy factor.

Discussing this issue thoroughly would go beyond the scope of this paper, but let CTFs serve as useful counterexamples. Hackers construct tasks within the community and they understand that programing a task and playing it are two sides of the same coin. The boundary between a player and an arbiter becomes even more complex than the boundary between an ethnographic observer and an ethnographic participant. In the case of more traditional e-sports, organizers set up a local instance of a more global game. This instance is more connected to an event, whereas the game changes following the software producer's patches and interests. This marks an interesting difference in studying the political economies of e-sports. What is the major source of income is not only the viewership and advertisement of an event, but also the game as a product.

In her newer approach laid out in Ethnography for the Internet (2015), Hine moves away from the 'Internet as a place' metaphor. The new methodology focuses on the Internet understood as embedded, embodied, and everyday. According to the author, when the digital permeates the existing institutions and objects, and when one cannot tell the difference between the digital and the non-digital, then the Internet is embedded. This is the first premise and Hine applies this especially to the rethinking of places and identities. The second premise is about embodiment and draws heavily from the concepts of cyborgs (Haraway 1987) as well as other texts on digital/body liminality. This is useful for studies of the presentation of self (Smith and Sanderson 2015) and investigating the body within e-sports. For me, however, the cyborgish liminalities are first and foremost an important source for auto-ethnography, as I will mention further in the article. The third premise is about the Internet as the everyday, the mundane, the non-special; as an infrastructure for everyday life. I have already discussed this premise and I will return to it when exploring the theoretical usefulness of infrastructures.

\section{On uses of netnography - infrastructures, indexicalities, and genres}

If Hine works within anthropology, then Robert V. Kozinets (2011) came from a space less laden with self-reflexivity. Where Hine considered the digital as an undiscovered land, Kozinets took it for granted. He situates netnography somewhere between close readings of particular texts and big data col- 
lection mechanisms (Kozinets 2011:4). It is open to inclusion of non-digital methods, but the digital is both the start and the finish of a research cycle. This approach also encompasses a broader range of tools than those included by Hine. In netnography there is room for every technique, from almost quantitatively representative full message-monitoring to almost passive social-media-listening. Apart from this methodological ecumenism, this approach also has other advantages. I would like to focus on those related to non-humans, online/offline combination, and the genres of netnography.

The notion of non-human actors is taken from ANT (Latour 2005), which not only enriches the array of interests, but also makes wide-range political consequences easier to analyze. If the digital tools are fragments of "society made durable," then one can see the Internet as a massive, visible highway for agents acting at a distance. Perhaps this comes from my background in engineering, but for me there is one significant gain from this approach, namely that within it technologies and various software packages are materializations of social facts. They are becoming traceable and easier to verify. If there are beauties and tragedies hidden in massive quantitative data, they are also to be found in small qualitative tidbits heard when listening to IT technicians, community caretakers, and other people who make things go smoothly (Vertesi et al. 2019).

Based on this tradition, I would like to offer a piece of advice with regard to e-sports research. When one sees a digital and humanlike actor, they should try to figure out what non-human factors make up its qualities. And vice-versa; if one see a system, a program, or a network, they should try to figure out exactly what humanlike factors make it as it is. If this sounds reasonable, using Susan Leigh Star's theory of infrastructure (Leigh Star 1999), as it is much more developed than that of Kozinets' and much easier to apply than that of Latour's.

This approach goes naturally with the second point of interest. Kozinets argues to drop the "digital as a space" metaphor (2011:68) in favor of the semiotics of indexicality, as presented in Ethnography and Virtual Worlds (Boellstorff et al. 2012). In short, the authors assume that the Internet is a technology, similarly to how language is seen by McLuhan. Rather than seeing the Internet as a space, it is better to analyze different types of referencing or to focus on technologies and details of a particular community-tool symbiosis, as well as on how different digital media convey messages and how these messages shape different relations between individuals and communities. This makes netnography close to culture and communication studies, as both are more individualistic and less structural. Groups and group processes are to be examined at the level of singular experiences and their media backbone.

This is the approach that Kozinets describes as Symbolic Netnography (2011:248). As the name suggests, it would be closest to semiotics and communication studies. Whenever I focused on the meanings and symbols of CTFs (Figure 1), I was practicing it. When I used massive data, possibly with software automation, I was closer to Digital Netnography. If I focused on the closeness with community and on emotions and rituals that bind the group, I would be doing humanist netnography. Lastly, if I were exploring the changes in myself as the netnographer, I would be doing Autonetnography.

These terms are not as widely used as the 'netnography' notion itself. Despite this, they show that Kozinets' approach is rather comprehensive, en- 
compassing multiple fields outside of the more traditional heritage.

\section{Problems with netnography - self- reflection and distance}

This comprehensiveness comes with a cost. Netnography was accused of being a "rather simple technique for virtual marketing research" (Jemielniak 2018:18, translation mine). In 2017, a group of qualitative researchers did a literature review on papers that had used netnography (Costello, McDermott, and Wallace 2017). It turned out that the term had been used even more loosely than in Kozinets' 'anthropologically unburdened' proposal.

However, questions are still there no matter how one calls a method. How is the researcher changed by the participants? How does ethnography shape its makers? What is the role of self-reflection in observations? All of these are also asked by regular ethnographers (Strathern 1999). Kozinets also recognizes the relevance of autonetnography, situating it among three other types of netnography, to which I will return soon. He admits that in his own fieldwork he did not explore this topic, but still maintains its importance in the handbook. Though he gives no example to follow, there is at least encouragement.

In this light, I shall try and provide an example of such autoethnographic reflection. During one event, I remember being overloaded with sensory stimuli. There was a crowd of hackers inside of a bigger hacking convention. CTF players sat beside members of different hackerspaces, and everything was big and loud. The game was just one thing among other hacking practices. The key match-game was played and discussed at tables. It was invisible, as it blended into the crowd. It was palpable, as chang- es in points were met with whispers and applause from the whole room, even from non-participants. I felt excited and confused. I wanted to understand the game, but I could not find it. I was part of the audience, but I was not able to tell what the state of play is. There were only minutiae, recorded scrapes of conversations and comments on the actions in the game.

I decided to learn from the players. I sat next to them, I waited patiently for their breaks. I quieted myself, tried to figure out the game on my own. Then I recorded short, impromptu interviews during the breaks. Not about the players' backstories and biographies, but about details of the tasks. I downloaded the questions, opened chats with comments. I asked some hackers to comment on the game for me.

After a few games, I learned even more. Not only about the game, but also about myself. I started to feel the flow, the focus of the participants. This unique sharpness of the mind, this absolute immersion into the abstraction. I had had similar experiences when I learnt physics or played chess, but in sociology it came rarely. I felt both tired and excited. I did not want to interrupt the games, but at the same time I craved for more data, more inputs, more stimuli. I wanted more, but I was afraid to spoil the bliss.

The last stage was when I thought about not only sharing this mix of mind and emotions, but also when I decided to let myself loose. I opened my CAQDAS software, I started to free-write, simultaneously detailing the observations and analyzing them theoretically. The hackers were playing their games; I was playing mine. After all, all black boxes exist to be opened - if not with software hacks and reverse engineering, then with sociology and phi- 
losophy. Tools are different, but the joy of the puzzle is universal.

This approach can be plausible for the general scope of e-sports. Perhaps the classic studies of sports events and crowd ethnography are almost directly applicable to e-sports. However, what can digital ethnography bring to this discussion? What might have been missed to date when studying events?

\section{Digital ethnography}

Immersion is nothing new in the netnography of sports (Næss 2017), neither is self-reflection or autoethnography (Hoeber and Kerwin 2013). All of these were also discussed within digital ethnography, netnography, or works discussing similar topics (Boellstorff et al. 2012). Thus, there is no wonder that these themes might also be found in a proposal that came with Digital Ethnography (Pink et al. 2016).

Among its founding ideals one can locate multiplicity, which in practice means that there are many ways to include the digital in ethnography. Let is imagine two examples. One will be a regular study of infrastructure with emphasis on software and hardware as well as their paradoxical involvements in digitality, without a significant online presence (Dourish 2017), but with a deep interest in the minutiae of its working instead. The second one will be about employing Marxist critiques of social media when studying Facebook communications (Beverungen, Böhm, and Land 2015). Within Kozinets' or (earlier) Hine's frameworks, the latter example comes closer to these authors' proposals. Conversely, both will equally count as examples of digital ethnography. The argument behind it goes like this: 'If participants do not make a significant distinction between the online and the offline, then why should we fo- cus on it in our methodologies?' This is especially handy for studying e-sports, as it allows for moving away from rather pointless debates about whether e-sport really is a sport. This notion is even more present in the second premise, the one about digital non-digital-centric-ness. In a way, this paper is an example of it, i.e. taking the digital as the everyday, which it is for some people.

Openness and reflexivity might sound as classical methodological principles; it would be hard to find asocial scientist who does not advocate for some form of reflexivity. In opposition to Kozinets and Hine, digital ethnography devotes more attention on researchers' consciousness of the tools they use to manage data. This is even more emphasized by the last premise, the one which focuses on alternative modes of communication.

For me, however, the primary appeal of digital ethnography lies elsewhere. While I enjoyed Kozinets' concepts of genres, ultimately they felt a bit flat, as they were mostly proposals and not actual and finished works. The digital-ethnography proposal is quite the opposite, i.e. it is built on a discussion of the existing works. The basis of the categorization is the frame; a theoretical strain between particular studies and social theories. I will discuss these frames, their theoretical roots, and my comments on their application in the context of e-sports.

Studies based on experiences share roots with pragmatist and phenomenological traditions, which is why they are likely to go along with studies concerning bodies, senses, or microscale intimate applications of the digital in the individual sphere. This approach goes naturally with the sociology of sport and the ethnographies of physical activities, such as boxing (Darmas 2019) or the self-presentation of ath- 
letes (Smith and Sanderson 2015). The question of the body in e-sports, its duplicity and constant shift between invisibility, negligence, and care seems to be particularly open to this vein of exploration. My interests lie elsewhere, but my studies also benefited from a bit of the phenomenology of the digital. This resonates well with ethnographical studies of smell and cognition (Alač 2020), found in seemingly distant cognitive anthropology. This approach is also in line with the call for embodiment made in the ethnography-for-the-Internet approach.

The lens of practices shifts focus toward a slightly less individualistic approach, following Pierre Bourdieu's and Theodore R. Schatzki's contributions as well as more open-ended discussions of 'media as practice'. This naturally resonates with studying fan practices and amateur sports, where openness to different actions and a lack of rigor are part of characteristics. While authors missed this reference, the approach goes naturally with the application of Bourdieu's theory in the form of digital habitus and information capital (Ignatow 2020). As a sociologist, I consider it as a useful link for discussing the issues of power and prestige that are connected with e-sports.

While I appreciate experiences-and-practices approaches, I am less convinced by the digital ethnography's use of things as a methodological tool. In my studies, I used ANT, which deals with the same issues, but with different assumptions. With time, Imoved from ANT to a more interpretative or critical approach, but still within science studies. While a full comparison of non-human actors theories is beyond the scope of this paper, science studies' array of approaches to materiality and things provides more practical tools (e.g. the black-boxes theory, debates on politics of artifacts, or the theory about boundary objects and trading zones). For those interested in studying non-humans in e-sports, Iwould suggest some of the classic science-studies texts as a vantage point (Leigh Star and Griesemer 1989; Latour 1999; Collins, Evans, and Gorman 2010). While they might be slightly less sensitive to power plays, I found full-blown Marxist critiques (Soderberg 2013; Beverungen et al. 2015) more inspiring than the slightly mid-ground culturalist approach. If this not help, I would still recommend other concepts of virtuality and materiality (Dourish 2017) as well as following the discussion on the digital STS (Vertesi et al. 2019). But, as I said, I am particularly close to science studies, while other people can choose the lens differently. For example, they might find the digital-ethnography approach more useful, as it is certainly less technically- and theoretically-laden than science-studies counterparts.

The concept of social worlds is present in other branches of sociology as well as in studies of relations. Both perspectives are proposed within digital ethnography, but as they lie outside of my expertise, I would rather not comment on their applications. Especially interesting might be the lens of relationships, as it builds on theories by Margaret Mead and Erving Goffman. The same could be said about the lens of localities, which borrows some notions from the first wave of the Chicago School ethnographies.

The last lens focuses on events. I wish I had read it before conducting my studies. This approach has a lot in common with the concepts of ritual as developed by Emile Durkheim or Victor Turner, which influenced the sociology of sport (Guttmann 2012). Digital ethnography puts less emphasis on mass, communal, and direct rituals in favor of the media-events theory, which perfectly suits e-sports events. I do not wish to repeat the authors' argument, 
but I found it close to the studies of rituals in regular sports in terms of their politics (Schimmel 2017) and ideologies (Kossakowski et al. 2020). Similar avenue is surfacing in e-sports studies (Szablewicz 2016) as well as in analyses of Twitch streaming (Uva 2018). Certainly, a CTF match could be analyzed as a mediated event and as a ritual, which would naturally follow previous studies on hacking (Coleman 2010). This particular feeling of 'being a part of the crowd' is shared by CTFs, e-sports, and sports events.

\section{Endgame}

In this paper, I discussed several approaches to computer ethnography, using both literature and my ethnographical experience from researching hacking tournaments. I used virtual ethnography (Hine 2000) to show some roots of the family of methods and to demonstrate a central tension that is still present in studies of the Internet. I added elements of science and technology studies in order to reveal that e-sports can be analyzed cognitively and infrastructurally so that it can cast new light on the topic of field/space in the sociology of sports. Then I moved to netnography (Kozinets 2011) to discuss in detail the contemporary approaches, which remain agnostic toward anthropological perplexity. Here, by proxy of symbolic netnography, I showed the first meeting point with media theory and the indexicality approach. Then, I tried to sketch a brief autoethnography, with an emphasis on distance and flow. In the last part, I introduced the concept of digital ethnography. I employed this notion to move the digital from the center of attention and to gain some context due to the peripheral vision of the topic. As a result, the spotlight of studying e-sports can also move toward experiences, practices, things, social worlds, relationships, or events rather than repeating the digital discussion on the Internet as a foreign land. Finally, I demonstrated how I would use some of these illuminations in my own study.

If this was an exhausting and messy trip, then I believe that I managed to capture at least some of the confusion I had experienced among both hackers and methodologists. If there is one thing that I share with both these groups, it is the commitment to practicality, i.e. if something is wrong but it works, then it is not wrong after all. Also, something which is done is better than something which is perfect. Thus, if I presented several new tools for the game, then I am successful. If I failed to do so, I still hope that my mistakes will prove useful, at least as counterexamples if nothing more. Instead of a synthesis, I will finish the paper with some casual advice; I wish I had known it before, so perhaps the reader will find it useful, albeit non-systematic.

First, use physical closeness to pump up your digital research. Even sitting shoulder to shoulder helps. In the case of an e-sport tournament, it is even easier, as it often shares the event structure with a hacking tournament (Figure 3). If one considers the sport-asa-religion metaphor, they will see that the mess is a part of a mass and the interpretation is a part of the event. When one open themselves to the atmosphere, they can participate in the game on their own rights. So, feel free to switch between the roles of a fan, an ethnographer, and a commentator. Use the game not only as a source of data, but also as a rhythm (Schmidt et al. 2020), an emotional support that pushes own analysis, a drive for own pursuits. Try writing with a minimal level of consciousness, and occasionally overuse the caffeine and trash food.

One might focus on sharing the experience with the audience or they might shadow players or judges. They can analyze things in their own theoretical 
setup just as the players reach the apex of their play, trying to match their bliss of play with the observer's bliss of theorizing. I certainly claim that a shared experience of a flow or bliss, or any other parts of the 'magic of the game', can be considered as autoethnographic just as anything else can. If sadness and trauma are parts of our ethnographic bodies, so are joys, blisses, and fascinations.

For me, the greatest kick - the drug of the game is the constant switching between those perspectives. Embrace the chaos. Enjoy blending in with the community and enjoy the separation in your own thoughts. Understand the wide consequences, try to catch all the tornadoes without losing the amazement of a single butterfly. Be consistent in the curiosity, but allow yourself to be contradictory in viewpoints. Also, take headphones with good noise dampening, as sometimes the only way to be in the crowd is to isolate yourself from it. No matter how digital you are, a good notebook and a recorder that are separate from your smartphone will save you from a lot of trouble.

If ethnography is your game, devote yourself to it. Risk it, win it, mourn for it. Let it guide you. Let it scare, bedazzle, or exhaust you. Hate $i^{2}$ and care for it. Play it and let yourself be played.

\section{Funding}

The described research was funded by the Polish National Science Centre (Narodowe Centrum Nauki) within the Preludium research grant no. 2014/13/N/ HS6/04113.

\footnotetext{
${ }^{2}$ As an alternative, consider this quote from the hacker-favorite, i.e. the Wargames movie from 1983: "It's a strange game. The only winning move is not to play." Whether it also applies to ethnography is an open question.
}

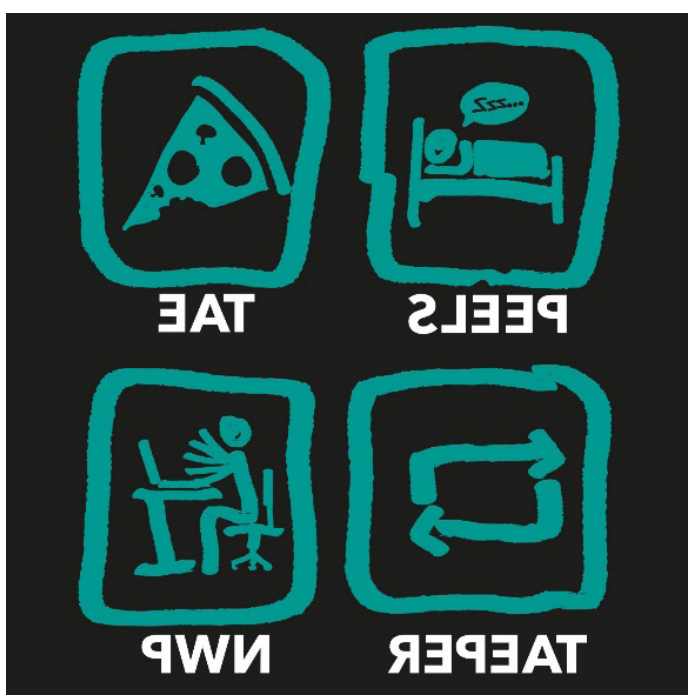

Figure 1. Eat, Sleep, Pwn, Repeat. Name of the hacking-CTF team, as well as the general CTF motto. It symbolizes the dedication to hacking through showing hacking as a necessary physiological need. At the same time, it serves as a self-parody, confirming the stereotype of a no-life hacker. Rather than analyzing it as a self-brag, I propose to see it as adescription of a desirable state of flow, i.e. when the hacker becomes an absolute part of the game. Similar imagery can be found in professional athletes' and professional musicians' social media ${ }^{3}$

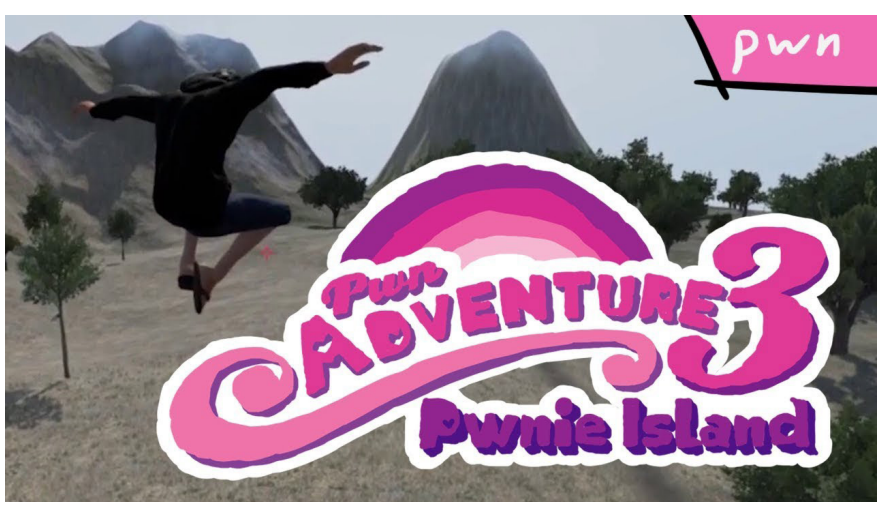

Figure 2. Space in e-sports. From CTFs, we know that space is not only about a room with players or a map

\footnotetext{
${ }^{3}$ Source: Popular meme in CTF community as well as name of one of the teams. https://twitter.com/EatSleepPwnRpt/status/802895773964836864/photo/1 (access 8.10.2021).
} 
used for the game. In the case of Pwnie Island, the map is to be used and exploited, both directly and on the programing level. Each time the players play on the map, they also play with the map. The physics of the map is hackable and so are its resources or terrain. This shows that spaces in e-sports are malleable and updated on each playthrough. They also exist as an element shared between the players and the audience. The situation from classic sports is reversed. There are multiple instances of the same map, accessible both to the audience and the players, while spaces are negotiated also by the producers of the game as well as its arbiters and modders ${ }^{4}$

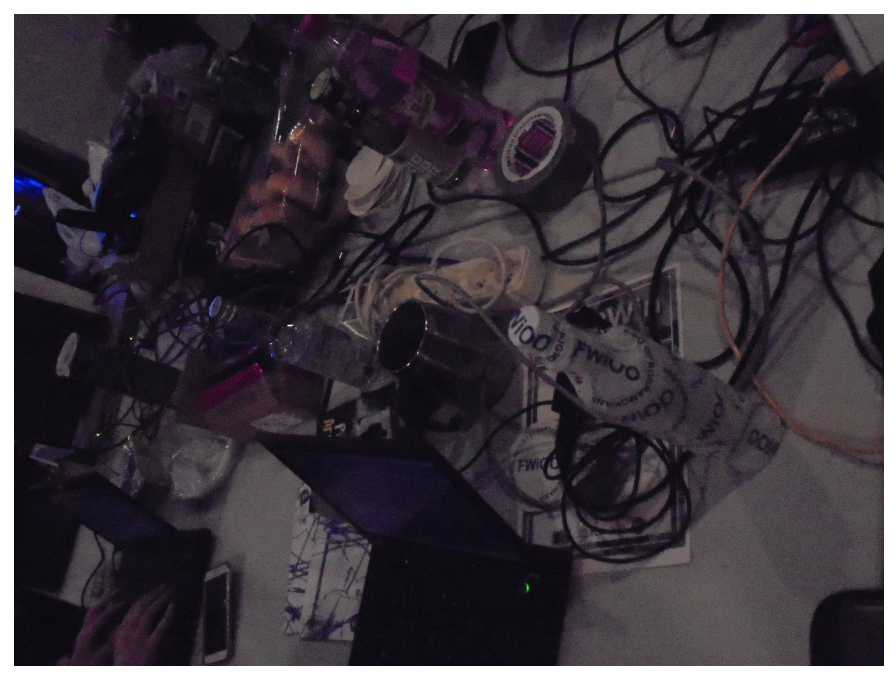

Figure 3. A table during CTF games. A mess and a mass: caffeine, wires, and duct tape. If one cannot switch between order and disorder, then they are missing a part of the game. I consider it to be an extra challenge, an additional thing that can overload cognition or guide it. By adding noise and distraction, players enhance their cognitive stakes and demonstrate their prowess. Also, noise and mess act both as a guideline and misguidance. One should neither completely ignore it nor fall for it. Few things are dearer to hackers than a good paradox (Source: Author).

\footnotetext{
${ }^{4}$ Source: Website of one of the CTF tasks: https://www.pwnadventure.com/ (access 8.10.2021)
}

\section{References}

Abanazir, Cem. 2018. "Institutionalisation in E-Sports." Sport, Ethics and Philosophy 13(2):117-131.

Alač, Morana. 2020. "Beyond Intersubjectivity in Olfactory Psychophysics I: Troubles with the Subject." Social Studies of Science 50(3):440-473.

Beverungen, Armin, Steffen Böhm, and Chris Land. 2015. “Free Labour, Social Media, Management: Challenging Marxist Organization Studies." Organization Studies 36(4):473-489.

Boellstorff, Tom et al. 2012. Ethnography and Virtual Worlds: A Handbook of Method. Princeton: Princeton University Press.

Caliandro, Alessandro. 2017. “Digital Methods for Ethnography: Analytical Concepts for Ethnographers Exploring Social Media Environments." Journal of Contemporary Ethnography 24(3):270-298.

Coleman, E. Gabriella. 2010. "The Hacker Conference: A Ritual Condensation and Celebration of a Lifeworld." Anthropological Quarterly 83(1):47-72.

Collins, Harry, Robert Evans, and Michael E. Gorman. 2010. “Trading Zones and Interactional Expertise." Pp. 7-22 in Trading Zones and Interactional Expertise, edited by M. E. Gorman. Cambridge, MA: MIT Press.

Costello, Leesa, Marie-Louise McDermott, and Ruth Wallace. 2017. "Netnography: Range of Practices, Misperceptions, and Missed Opportunities." International Journal of Qualitative Methods 16(1).

Darmas, Marcin. 2019. Na dystans. Rozważania socjologiczne o boksie. Warsaw: Wydawnictwo Uniwersytetu Warszawskiego.

Dourish, Paul. 2017. The Stuff of Bits. An Essay on the Materialities of Information. Cambridge: MIT Press.

Escobar, Arturo. 1994. "Welcome to Cyberia: Notes on the Anthropology of Cyberculture." Current Anthropology 35(3):211-231.

Guttmann, Allen. 2012. From Ritual to Record: The Nature of Modern Sports. New York: Columbia University Press.

Haraway, Donna. 1987. "A Manifesto for Cyborgs: Science, Technology, and Socialist Feminism in the 1980s." Australian Feminist Studies 2(4):1-42.

Hine, Christine. 2000. Virtual Ethnography. London, UK/Thousand Oaks, CA: SAGE. 
Hine, Christine. 2015. Ethnography for the Internet: Embedded, Embodied and Everyday. London: Routledge, Taylor \& Francis Group.

Hoeber, Larena and Shannon Kerwin. 2013. “Exploring the Experiences of Female Sport Fans: A Collaborative Self-Ethnography." Sport Management Review 16(3):326-336.

Ignatow, Gabe. 2020. Sociological Theory in the Digital Age. Abingdon, UK/New York, NY: Routledge.

Jakubowska, Honorata. 2017. Skill Transmission, Sport and Tacit Knowledge: A Sociological Perspective. Milton: Taylor \& Francis.

Jemielniak, Dariusz. 2018. “Socjologia 2.0. O potrzebie łączenia big data $z$ etnografią cyfrową, wyzwaniach jakościowej socjologii cyfrowej i systematyzacji pojęć." Studia Socjologiczne 2(229):7-29.

Knorr Cetina, Karin. 1999. Epistemic Cultures: How the Sciences make Knowledge. Cambridge, MA: Harvard University Press.

Kossakowski, Radosław, Przemysła Nosal, and Wojciech Woźniak. 2020. Politics, Ideology and Football Fandom: The Transformation of Modern Poland. Abingdon, UK/New York, NY: Routledge.

Kozinets, Robert V. 2011. Netnography. Doing Ethnographic Research Online. Los Angeles, CA: SAGE.

Latour, Bruno. 1987. Science in Action: How to Follow Scientists and Engineers Through Society. Cambridge, MA: Harvard University Press.

Latour, Bruno. 1999. Pandora's Hope: Essays on the Reality of Science Studies. Cambridge, MA: Harvard University Press.

Latour, Bruno. 2005. Reassembling the Social: An introduction to Actor-Network-Theory. Oxford, UK/New York, NY: Oxford University Press.

Leigh Star, Susan. 1999. “The Ethnography of Infrastructure." American Behavioral Scientist 43(3):377-391.

Leigh Star, Susan and James R. Griesemer. 1989. “Institutional Ecology, 'Translations' and Boundary Objects: Amateurs and Professionals in Berkeley's Museum of Vertebrate Zoology, 1907-39." Social Studies of Science 19(3):387-420.

Muntanyola-Saura, Dafne and Raúl Sánchez-García. 2018. “Distributed Attention: A Cognitive Ethnography of Instruction in Sport Settings." Journal for the Theory of Social Behaviour 48(4):433-454.
Næss, Hans Erik. 2017. "Authenticity Matters: A Digital Ethnography of FIA World Rally Championship Fan Forums." Sport Management Review 20(1):105-113.

Pink, Sarah et al. 2016. Digital Ethnography: Principles and Practice. Los Angeles, CA/London, UK/New Delhi/Singapore/ Washington, DC: SAGE.

Reitman, Jason G. et al. 2020. “Esports Research: A Literature Review." Games and Culture 15(1):32-50.

Schimmel, Kimberly S. 2017. "Not an 'Extraordinary Event': NFL Games and Militarized Civic Ritual." Sociology of Sport Journal 34(1):79-89.

Schmidt, Steffen C. E. et al. 2020. "The Influence of Cortisol, Flow, and Anxiety on Performance in E-Sports: A Field Study." BioMed Research International 2020(2):1-6.

Seippel, Ørnulf. 2018. “Topics and Trends: 30 Years of Sociology of Sport." European Journal for Sport and Society 15(3):288-307.

Smith, Lauren Reichart and Jimmy Sanderson. 2015. “I'm Going to Instagram It! An Analysis of Athlete Self-Presentation on Instagram." Journal of Broadcasting \& Electronic Media 59(2):342-358.

Soderberg, Johan. 2013. “Determining Social Change: The Role of Technological Determinism in the Collective Action Framing of Hackers." New Media \& Society 15(8):1277-1293.

Strathern, Marilyn. 1999. Property, Substance and Effect: Anthropological Essays on Persons and Things. London, UK/New Brunswick, NJ: Athlone Press.

Szablewicz, Marcella. 2016. “A Realm of Mere Representation? 'Live' E-Sports Spectacles and the Crafting of China's Digital Gaming Image." Games and Culture 11(3):256-274.

Uva, Domenico. 2018. Competing Online: A Netnographic Study on Twitch Influencers. Sao Paolo: Escola De Administracao de Empresas.

Vertesi, Janet, David Ribes, and Carl DiSalvo, eds. 2019. DigitalSTS: A Field Guide for Science \& Technology Studies. Princeton: Princeton University Press.

Zaród, Marcin. 2018. Aktorzy-Sieci w kolektywach hakerskich. Doctoral dissertation. Uniwersytet Warszawski, Warsaw. Wydział Filozofii i Socjologii. Retrieved January 13, 2021 (http:// depotuw.ceon.pl/handle/item/2909). 


\section{Citation}

Zaród, Marcin. 2021. “Tools of the game. Qualitative digital methodologies for the e-sports research.” Przeglad Socjologii Jakościowej 17(1):26-40. Retrieved Month, Year (www.przegladsocjologiijakosciowej.org). DOI: http://dx.doi.org/10.18778/1733-8069.17.1.03

\section{Sprzęt do gry. Narzędzia do cyfrowych badań jakościowych w obszarze e-sportu}

Abstrakt: Artykuł adaptuje metodologie z wybranych obszarów jakościowej socjologii cyfrowej na potrzeby problemów badawczych specyficznych dla socjologii e-sportu. Proponowane koncepcje są oparte na krytycznym przeglądzie istniejących teorii oraz przypadkach z własnej etnografii e-sportu hakerskiego. Zaplecze teoretyczne stanowią różne koncepcje socjologii cyfrowej: etnografii wirtualnej, netnografii i etnografii cyfrowej. Przegląd uzupełniają perspektywy ze studiów nad nauką oraz badań mediów i komunikacji.

Z koncepcji wirtualnej etnografii zaczerpnięto perspektywę poznawczą, przy jednoczesnym wyborze innych podejść do wirtualności, roli miejsca i teorii infrastruktury. Z koncepcji netnografii czerpie wskazania co do gatunków netnografii, przy zaproponowaniu bardziej praktycznych podejść do autoetnografii. Z etnografii cyfrowej artykuł bierze ramy badawcze i pokazuje konteksty ich użycia w przypadkach e-sportu. Ostatnia część artykułu koncentruje się na poradach praktycznych, zaczerpniętych z analizy innych koncepcji i praktyki własnej.

Słowa kluczowe: socjologia sportu, socjologia e-sportu, etnografia, netnografia, socjologia cyfrowa 